\title{
Effects of gender and dietary date palm extract on performance, carcass traits, and antioxidant status of Japanese quail
}

\author{
M. Bolacali ${ }^{1, \#, ~ K . ~ I r a k}{ }^{2}$, T. Tufan ${ }^{3} \&$ M. Küçük ${ }^{4}$ \\ ${ }^{1}$ Siirt University, Faculty of Veterinary Medicine, Department of Animal Breeding and Husbandry, Siirt, Turkey \\ ${ }^{2}$ Siirt University, Faculty of Veterinary Medicine, Department of Biochemistry, Siirt, Turkey. \\ ${ }^{3}$ Siirt University, Veterinary Medicine Faculty, Department of Animal Nutrition and Nutritional Disease, Siirt, Turkey \\ ${ }^{4}$ Gazi University, Health Services Vocational School, Department of Medical Services and Techniques, Ankara, Turkey
}

(Received 1 January 2021; Accepted 21 February; Published 14 June 2021)

\author{
Copyright resides with the authors in terms of the Creative Commons Attribution 4.0 South African Licence. \\ See: http://creativecommons.org/licenses/by/4.0/za \\ Condition of use: The user may copy, distribute, transmit and adapt the work, but must recognise the authors and the South African \\ Journal of Animal Science.
}

\begin{abstract}
This research examined effects of gender and dietary inclusion of date palm extract (DPE) on growth, carcass characteristics, oxidative status and serum characteristics of Japanese quail. One thousand chicks were allocated to five replicates of treatment and gender groups composed of 20 chicks. The treatments were a basal diet and four groups augmented with $0.25 \%, 0.50 \%, 0.75 \%$, and $1.00 \%$ DPE. The interaction of gender and treatment was significant for bodyweight (BW) at 42 days, average daily bodyweight gain (BWG), feed intake (FI), weights of most carcass components, and the serum profile. Females had better performance to 42 days than males $(P<0.05)$. In addition, females had higher hot and cold carcass weights, breast percentage, liver percentage, intestine percentage, total protein, albumin, triglyceride (TRIG), total antioxidant status (TAS), total oxidant status (TOS), and oxidative stress indexes (OSIs) $(P<0.001)$. Males had higher percentages of hot carcass, cold carcass and heart, and their levels of cholesterol (CHOL), highdensity lipoprotein (HDL), alanine aminotransferase (ALT), and aspartate aminotransferase (AST) values were greater than females $(P<0.001)$. Birds fed $0.50 \%$ DPE grew faster, were more efficient, and had heavier live and carcass weights at 42 days than those fed the basal diet. However, treatment effects and their interaction with gender on growth, feed intake and the serum profile were unremarkable compared to the gender main effect. Dietary augmentation with $0.50 \%$ DPE might enhance the performance of quail between 14 and 42 days old.
\end{abstract}

Keywords: blood parameters, carcass attributes, growth performance, Japanese quail, Phoenix dactylifera L.

${ }^{\#}$ Corresponding author: bolacali@gmail.com

\section{Introduction}

The use of antibiotics as growth promoters in poultry was banned in European Union countries in 2006 because of concern about antimicrobial resistance to pathogenic bacteria and the accumulation of antibiotic residues in poultry production (Castanon, 2007; Tufan \& Arslan, 2020). Studies on the use of natural performance and growth promoters have increased in recent years. Among them, the use and benefits of date palm have attracted interest.

Global date palm production reached approximately 9.07 million tons in 2019 (FAO, 2021). But nearly $20 \%$ of this production is waste, and is not suitable for human consumption. This rate increases to $30 \%$ when it includes by-products from the date palm. However, date palm waste and by-products constitute important nutritional food sources for animals (Sami et al., 2016; Al-Salhie et al., 2017) because of their antibacterial (Salem et al., 2018), anticancer, anti-inflammatory (El Abed et al., 2018), antilipidemic, antihyperglycemic (Hussein et al., 2015), hepatoprotective, and nephroprotective effects (Romano et al., 2013). The addition of dates and by-products to poultry rations increased growth and fattening performance (Abudabos et al., 2015; Attia \& Attia, 2015; Tareen et al., 2017), affected protein metabolism positively (Mohammed, 2013), and had antilipidemic effects (Al-Harthi et al., 2009).

Dates were used successfully as an alternative carbohydrate source to maize and barley in the rations of quail (Vandepopuliere et al., 1995), broilers (Abudabos et al., 2015), and layers (Nagib et al., 1994). However, the high hygroscopic features of the waste made it difficult to use in industrial feed production, as it 
could not be preserved as flour or powder (Belal et al., 1999). To eliminate this problem, date palm waste can be mixed with warm water to ensure economic efficiency and included with various feeds, and DPE may be added instead of waste.

Japanese quail have received significant attention in recent years for their resistance to disease and for use for meat and egg production (Ahmad et al., 2018). To date, there are no studies in the literature on the use of DPE as a feed additive for quail. The aim of the present study was to determine the effects of gender and dietary administration of DPE on growth performance, carcass characteristics, oxidative status, and serum parameters in Japanese quail.

\section{Materials and methods}

This study was approved by Siirt University Animal Researches Local Ethics Committee (decision number 2020/05/04) and conducted at the Research Centre for Protection and Rehabilitation of Wild Animals. The experiment used a completely randomized design with a $2 \times 5$ factorial arrangement of gender and dietary treatment. A total of 1000 (500 males and 500 females) 14-day-old Japanese quail (Coturnix coturnix japonica) chicks were allotted to ten trial groups, which were formed by considering two factors for gender and five for dietary treatment. Five replicates were used. Over the experimental period, the quail were fed grower (14-28 days old) and finisher (29 - 42 days old) basal diets (Table 1), which were formulated to meet their nutrient requirements (NRC, 1994). Date palm extract powder was provided by Deva Company (Manisa, Turkey). Its total phenolic compound content was calculated with the FolinCiocalteu method (946.65 mg gallic acid/100 g).

Table 1 Ingredient composition and analysed content of the nutrients in diets for quail

\begin{tabular}{|c|c|c|c|c|c|}
\hline \multirow{2}{*}{ Ingredients $\left(\mathrm{g} \mathrm{kg}^{-1}\right)$} & \multicolumn{2}{|c|}{ Diet } & \multirow{2}{*}{ Nutritional content, g/kg } & \multicolumn{2}{|c|}{ Diet } \\
\hline & Grower & Finisher & & Grower & Finisher \\
\hline Yellow corn & 450.0 & 527.8 & Dry matter & 900.5 & 898.3 \\
\hline Wheat & 83.1 & 90.0 & Metabolic energy, kcal/kg & 3.005 & 2.905 \\
\hline Vegetable oil & 30.0 & 10.0 & Crude protein & 239.0 & 200.0 \\
\hline Soybean meal ( $48 \%$ crude protein) & 300.0 & 270.0 & Crude fat & 46.0 & 28.0 \\
\hline Fish meal (64\% crude protein) & 35.0 & & Crude fibre & 44.2 & 44.5 \\
\hline Sunflower meal (32\% crude protein) & 80.0 & 70.0 & Crude ash & 56.2 & 61.0 \\
\hline Lime stone & 9.5 & 12.5 & Calcium & 8.2 & 9.2 \\
\hline Vitamin and mineral premix ${ }^{1}$ & 2.5 & 2.5 & Potassium & 3.7 & 3.8 \\
\hline Salt & 3.5 & 3.5 & Sodium & 2.0 & 1.8 \\
\hline Di-calcium phosphate & 4.1 & 13.5 & Chloride & 2.8 & 2.6 \\
\hline Antioxidant & 0.8 & & Methionine + cysteine & 8.5 & 7.1 \\
\hline DL-Methionine & & 0.2 & Lysine & 13.0 & 10.3 \\
\hline \multirow[t]{2}{*}{ L-Threonine } & 1.5 & & Threonine & 10.6 & 7.6 \\
\hline & & & Tryptophan & 3.1 & 2.7 \\
\hline
\end{tabular}

${ }^{1}$ Per kilogram of diet, vitamin A: 13,000 IU, vitamin D3: 3,500 IU, vitamin E: $100 \mathrm{mg}$, vitamin K3: $3 \mathrm{mg}$, vitamin B1: $3 \mathrm{mg}$, vitamin B2: $8 \mathrm{mg}$, vitamin B6: $6 \mathrm{mg}$, vitamin B12: $30 \mathrm{mg}$, niacin: $30 \mathrm{mg}$; calcium-D-panthotenate: $8 \mathrm{mg}$, folic acid: $2 \mathrm{mg}$, vitamin C: $70 \mathrm{mg}$, D-biotin: $70 \mathrm{mg}$, choline chloride: $200 \mathrm{mg}$, canthaxanthin: $2 \mathrm{mg}$, apo carotenoic acid ester: $0.75 \mathrm{mg}$, manganese: $120 \mathrm{mg}$, zinc: $100 \mathrm{mg}$, iron: $90 \mathrm{mg}$, copper: $16 \mathrm{mg}$, iodine: $1.5 \mathrm{mg}$, cobalt: $0.75 \mathrm{mg}$, selenium: $0.30 \mathrm{mg}$

The quail were treated per gender as control (basal diet), $0.25 \%$ DPE (basal diet $+0.25 \%$ DPE), 0.50\% DPE (basal diet + 0.50\% DPE); $0.75 \%$ DPE (basal diet + $0.75 \%$ DPE), and $1.00 \%$ DPE (basal diet + $1.00 \%$ DPE). The chicks of all replicate groups were housed in cages measuring $45.5 \times 68.8 \times 30.0 \mathrm{~cm}$. Feed and water were provided ad libitum. Heat and 24-hour lighting were provided. The study was conducted over 28 days.

Live bodyweight (LBW) (g) was recorded at 14 days old, then once weekly throughout the study. Overall, weekly net feed intake was calculated by measuring the daily leftover feed. Average daily 
bodyweight gain (ADG) (g/day/bird), daily feed intake ( $F I)(g /$ day/bird), and the feed conversion ratio (FCR) $(\mathrm{g} / \mathrm{g})$ were then calculated.

On day 42, a total of 100 male and 100 female quail were slaughtered after LBW had been determined. Twenty chicks were randomly selected from each group from those whose LBW was closest to average. The slaughtering and separation into carcass parts were performed according to Genchev and Mihaylov (2008).

On day 42, anticoagulant tubes were used to obtain blood samples from 10 quail in each group of both genders. Blood samples were centrifuged at $3000 \mathrm{rpm}$ for $10 \mathrm{~min}$, and the resulting sera were stored at -20 ${ }^{\circ} \mathrm{C}$ until further analysis. The total protein (TP), albumin (ALB), triglyceride (TRIG), cholesterol (CHOL), highdensity lipoprotein (HDL), alanine aminotransferase (ALT), and aspartate aminotransferase (AST) levels in the serum were analysed (ADVIA 1800 Chemistry System). Total antioxidant status (TAS) and total oxidant status (TOS) were assessed with kits (Rel Assay Diagnostics, Gaziantep, Turkey), and spectrophotometric methods (Erel, 2004; Erel, 2005). The ratio of TOS to TAS revealed the oxidative stress index (OSI) (Harma et al., 2003).

The data were analysed with a factorial model of the general linear model procedure of SPSS software (SPSS version 23.0, IBM Corp., Armonk, NY, USA). The interaction of feed supplementation and gender on LBW, ADG, FI, FCR, slaughter and carcass weight and percentage, blood parameters, and oxidative stress parameters were determined with the PROC GLM procedure. The model was

$$
Y_{i j k}=\mu+D P E_{i}+G_{j}+(D P E x G)_{i j}+e_{i j k}
$$

where: $Y_{i j k}$ was a response variable (LBW, ADG, FI, FCR, slaughter and carcass weight/percentage, blood parameters and oxidative stress parameters),

$\mu=$ the overall mean common to all observations,

$D P E_{i}=$ the fixed effect of the dietary treatment $(i=5)$,

$G_{j}=$ the fixed effect of gender $(\mathrm{j}=2)$,

$(D P E x G)_{i j}=$ the first order interaction of dietary treatment and gender, and

$e_{i j k}=$ random residual error.

Growth-related performance was analysed in biweekly periods (days 14 to 28 and 29 to 42 ) and across the experiment (days 14 to 42 ). Effects were declared significant at $P \leq 0.05$. Post hoc comparisons of the means were done with Duncan's multiple range test.

\section{Results and Discussion}

The interaction of gender and treatment for LBW approached significance at days 21 and 28 and then became significant (Table 2). Likewise, the interaction effects on ADG were significant over all time intervals. However, the effects of interaction and of the dietary treatments were relatively small compared with those of gender, which were highly significant from day 28 onwards $(P<0.001)$. Female quail were heavier than males at days 28,35 , and 42 . The addition of DPE to quail rations increased LBW at day $42(P<0.001)$ compared with birds fed the basal diet. Feeding $0.50 \%$ or more DPE increased LBW from day 28 onwards relative to the basal diet. The ADG of female quail was higher than that of males in the grower, finisher, and overall periods. The addition of $0.50 \%$ or more DPE to quail rations increased the ADG in the grower and finisher and overall periods. The highest and lowest ADG were in the $0.50 \%$ DPE female and $0.25 \%$ DPE male groups during the grower period, in the 1.00\% DPE female and control male groups during the finisher period, and in the $1.00 \%$ DPE female and $0.25 \%$ DPE male groups overall.

Feed intake of female quail was higher and FCR was lower than that of male birds in all periods (Table 3 ). With the exception of the $0.75 \%$ DPE group, the addition of DPE to quail rations decreased FI in the finisher and overall, and improved FCR relative to birds fed the basal diet. Feed conversion ratio was optimized by feeding an intermediate level of DPE. The highest and lowest FI were in the control male and control female groups during the grower period; in the $0.75 \%$ DPE female and $0.25 \%$ male groups during the finisher period; and in the $0.75 \%$ DPE female and $0.25 \%$ DPE male groups overall. Feed conversion ratio was lowest in the $0.50 \%$ DPE female group during the grower and overall, and in the $1.00 \%$ DPE female groups during the finisher period. Male quail that were not supplemented with DPE had the highest FCR in all periods. 
Table 2 Effects of dietary supplementation of date palm extract on live body weight and average daily gain of quail at various ages

\begin{tabular}{|c|c|c|c|c|c|c|c|c|c|}
\hline \multirow{2}{*}{ Group } & \multirow{2}{*}{ Gender } & \multicolumn{5}{|c|}{ Body weight } & \multicolumn{3}{|c|}{ Average daily gain } \\
\hline & & 14 days old & 21 days old & 28 days old & 35 days old & 42 days old & $14-28$ days & 28-42 days & $14-42$ days \\
\hline \multirow[t]{2}{*}{$1.00 \% \mathrm{DPE}$} & Male & 67.71 & 109.80 & 147.30 & $164.11^{\mathrm{cd}}$ & $175.53^{\mathrm{cd}}$ & $5.68^{\mathrm{C}}$ & $2.02^{\mathrm{e}}$ & $3.85^{\mathrm{e}}$ \\
\hline & Female & 67.72 & 109.65 & 152.24 & $190.94^{a}$ & $212.84^{a}$ & $6.04^{\mathrm{a}}$ & $4.33^{a}$ & $5.18^{a}$ \\
\hline \multirow[t]{2}{*}{$0.75 \% \mathrm{DPE}$} & Male & 67.65 & 108.67 & 147.44 & $167.96^{\mathrm{b}}$ & $179.22^{b c}$ & $5.70^{\mathrm{C}}$ & $2.27^{d}$ & $3.99^{d}$ \\
\hline & Female & 67.74 & 111.01 & 152.90 & $191.29^{a}$ & $211.88^{\mathrm{a}}$ & $6.08^{a}$ & $4.21^{\mathrm{ab}}$ & $5.15^{\mathrm{a}}$ \\
\hline \multirow[t]{2}{*}{$0.50 \% \mathrm{DPE}$} & Male & 67.60 & 109.95 & 149.37 & $169.76^{\mathrm{b}}$ & $181.89^{b}$ & $5.84^{b}$ & $2.33^{d}$ & $4.08^{\mathrm{C}}$ \\
\hline & Female & 67.66 & 110.58 & 153.45 & $189.51^{\mathrm{a}}$ & $211.24^{\mathrm{a}}$ & $6.13^{a}$ & $4.13^{b c}$ & $5.13^{\mathrm{a}}$ \\
\hline \multirow[t]{2}{*}{$0.25 \% \mathrm{DPE}$} & Male & 67.61 & 108.48 & 144.06 & $161.70^{d}$ & $170.93^{d}$ & $5.46^{d}$ & $1.92^{\mathrm{ef}}$ & $3.69^{\dagger}$ \\
\hline & Female & 67.67 & 107.22 & 152.78 & $192.02^{\mathrm{a}}$ & $210.34^{a}$ & $6.08^{\mathrm{a}}$ & $4.11^{\mathrm{bc}}$ & $5.10^{\mathrm{ab}}$ \\
\hline \multirow[t]{2}{*}{ Control } & Male & 67.58 & 108.80 & 145.81 & $165.40^{c}$ & $172.12^{d}$ & $5.59^{c d}$ & $1.88^{\dagger}$ & $3.73^{f}$ \\
\hline & Female & 67.59 & 108.36 & 151.54 & $192.23^{a}$ & $208.36^{a}$ & $6.00^{\mathrm{a}}$ & $4.06^{c}$ & $5.03^{b}$ \\
\hline SE & & 0.50 & 0.65 & 0.83 & 0.91 & 1.02 & 0.05 & 0.05 & 0.03 \\
\hline $1.00 \% \mathrm{DPE}$ & & 67.72 & $109.73^{\mathrm{ab}}$ & $149.77^{\mathrm{ab}}$ & $177.52^{\mathrm{bc}}$ & $194.19^{b}$ & $5.86^{\mathrm{bc}}$ & $3.17^{\mathrm{a}}$ & $4.52^{b}$ \\
\hline $0.75 \%$ DPE & & 67.70 & $109.84^{\mathrm{ab}}$ & $150.17^{\mathrm{ab}}$ & $179.63^{a}$ & $195.55^{\mathrm{ab}}$ & $5.89^{\mathrm{ab}}$ & $3.24^{a}$ & $4.57^{\mathrm{ab}}$ \\
\hline $0.50 \%$ DPE & & 67.63 & $110.27^{\mathrm{a}}$ & $151.41^{a}$ & $179.64^{\mathrm{a}}$ & $196.57^{\mathrm{a}}$ & $5.98^{\mathrm{a}}$ & $3.23^{\mathrm{a}}$ & $4.61^{\mathrm{a}}$ \\
\hline $0.25 \% \mathrm{DPE}$ & & 67.64 & $107.85^{c}$ & $148.42^{b}$ & $176.86^{c}$ & $190.64^{c}$ & $5.77^{\mathrm{c}}$ & $3.02^{b}$ & $4.39^{c}$ \\
\hline Control & & 67.59 & $108.58^{\mathrm{bc}}$ & $148.68^{b}$ & $178.82^{C}$ & $190.24^{c}$ & $5.79^{b c}$ & $2.97^{b}$ & $4.38^{\mathrm{C}}$ \\
\hline SE & & 0.35 & 0.46 & 0.59 & 0.64 & 0.72 & 0.03 & 0.03 & 0.02 \\
\hline Male & & 67.63 & 109.14 & 146.79 & $165.79^{b}$ & $175.94^{b}$ & $5.65^{b}$ & $2.08^{b}$ & $3.87^{b}$ \\
\hline Female & & 67.68 & 109.36 & 152.58 & $191.20^{\mathrm{a}}$ & $210.93^{\mathrm{a}}$ & $6.07^{\mathrm{a}}$ & $4.17^{\mathrm{a}}$ & $5.12^{\mathrm{a}}$ \\
\hline SE & & 0.22 & 0.29 & 0.37 & 0.40 & 0.46 & 0.02 & 0.02 & 0.02 \\
\hline \multicolumn{10}{|c|}{ Source of variation } \\
\hline DPE & & 0.99 & $<0.1$ & $<0.01$ & $<0.01$ & $<0.01$ & $<0.01$ & $<0.01$ & $<0.01$ \\
\hline Gender & & 0.88 & 0.59 & $<0.01$ & $<0.01$ & $<0.01$ & $<0.01$ & $<0.01$ & $<0.01$ \\
\hline DPE $\times$ gender & & 1.00 & 0.07 & 0.07 & $<0.01$ & $<0.01$ & 0.01 & $<0.01$ & $<0.01$ \\
\hline
\end{tabular}

DPE: date palm extract
$\mathrm{a}, \mathrm{b}, \mathrm{c}, \mathrm{d}$
Within an effect and column, means a common superscript did not differ at probability $P=0.05$ 
Table 3 Effect of adding various levels of date palm extract to the rations of male and female quail on feed intake and feed conversion ratio based on performance from five replicate cages

\begin{tabular}{|c|c|c|c|c|c|c|c|}
\hline \multirow[b]{2}{*}{ Group } & \multirow[b]{2}{*}{ Gender } & \multicolumn{3}{|c|}{ Feed intake } & \multicolumn{3}{|c|}{ Feed conversion ratio } \\
\hline & & 14 - 28 days & 28 - 42 days & 14 - 42 days & 14 - 28 days & 28 - 42 days & $\begin{array}{c}14-42 \\
\text { days }\end{array}$ \\
\hline \multirow[t]{2}{*}{$1.00 \%$ DPE } & Male & 12.93 & $20.58^{c d}$ & $18.88^{d}$ & 2.29 & $10.24^{b}$ & $4.91^{b c}$ \\
\hline & Female & 12.52 & $26.17^{\mathrm{a}}$ & $22.48^{\mathrm{ab}}$ & 2.09 & $6.06^{\mathrm{e}}$ & $4.34^{\text {de }}$ \\
\hline \multirow[t]{2}{*}{$0.75 \%$ DPE } & Male & 12.55 & $20.47^{\text {cd }}$ & $19.77^{d}$ & 2.20 & $9.06^{c}$ & $4.96^{b c}$ \\
\hline & Female & 12.49 & $26.26^{\mathrm{a}}$ & $23.09^{\mathrm{a}}$ & 2.04 & $6.25^{\mathrm{de}}$ & $4.48^{d}$ \\
\hline \multirow[t]{2}{*}{$0.50 \%$ DPE } & Male & 12.60 & $20.47^{\mathrm{cd}}$ & $19.68^{d}$ & 2.17 & $8.81^{\mathrm{c}}$ & $4.83^{\mathrm{c}}$ \\
\hline & Female & 12.04 & $25.42^{b}$ & $21.74^{\mathrm{bc}}$ & 1.96 & $6.20^{\mathrm{de}}$ & $4.24^{\mathrm{e}}$ \\
\hline \multirow[t]{2}{*}{$0.25 \%$ DPE } & Male & 12.72 & $20.13^{d}$ & $18.86^{d}$ & 2.33 & $10.52^{b}$ & $5.10^{b}$ \\
\hline & Female & 12.01 & $26.18^{\mathrm{a}}$ & $21.99^{b}$ & 1.98 & $6.37^{\mathrm{de}}$ & $4.32^{\mathrm{de}}$ \\
\hline \multirow[t]{2}{*}{ Control } & Male & 13.54 & $21.01^{\mathrm{c}}$ & $20.92^{c}$ & 2.42 & $11.19^{\mathrm{a}}$ & $5.60^{\mathrm{a}}$ \\
\hline & Female & 11.91 & $25.94^{\mathrm{a}}$ & $21.67^{\mathrm{bc}}$ & 1.99 & $6.41^{d}$ & $4.31^{\mathrm{de}}$ \\
\hline$S E$ & & 0.43 & 0.18 & 0.35 & 0.08 & 0.11 & 0.07 \\
\hline $1.00 \% \mathrm{DPE}$ & & 12.73 & $23.38^{a}$ & $20.68^{b c}$ & 2.19 & $8.15^{c}$ & $4.63^{b c}$ \\
\hline $0.75 \%$ DPE & & 12.52 & $23.37^{\mathrm{a}}$ & $21.43^{\mathrm{a}}$ & 2.12 & $7.66^{d}$ & $4.72^{b}$ \\
\hline $0.50 \%$ DPE & & 12.32 & $22.94^{\mathrm{b}}$ & $20.71^{b c}$ & 2.07 & $7.51^{d}$ & $4.54^{\mathrm{C}}$ \\
\hline $0.25 \%$ DPE & & 12.37 & $23.16^{\mathrm{ab}}$ & $20.42^{c}$ & 2.15 & $8.44^{b}$ & $4.71^{b}$ \\
\hline Control & & 12.72 & $23.47^{\mathrm{a}}$ & $21.30^{\mathrm{ab}}$ & 2.21 & $8.80^{\mathrm{a}}$ & $4.96^{\mathrm{a}}$ \\
\hline$S E$ & & 0.30 & 0.13 & 0.24 & 0.05 & 0.07 & 0.05 \\
\hline Male & & $12.87^{\mathrm{a}}$ & $20.53^{b}$ & $19.62^{b}$ & $2.28^{a}$ & $9.96^{a}$ & $5.08^{a}$ \\
\hline Female & & $12.19^{b}$ & $25.99^{a}$ & $22.19^{a}$ & $2.01^{\mathrm{b}}$ & $6.26^{b}$ & $4.34^{b}$ \\
\hline SE & & 0.19 & 0.08 & 0.15 & 0.03 & 0.05 & 0.03 \\
\hline \multicolumn{8}{|c|}{ Source of variation } \\
\hline DPE & & 0.805 & 0.030 & 0.016 & 0.373 & 0.000 & 0.000 \\
\hline Gender & & 0.013 & 0.000 & 0.000 & 0.000 & 0.000 & 0.000 \\
\hline DPE $\times$ gender & & 0.444 & 0.005 & 0.000 & 0.343 & 0.000 & 0.000 \\
\hline
\end{tabular}

DPE: date palm extract

${ }_{a, b, c, d}$ Within an effect and column, means a common superscript did not differ at probability $P=0.05$

Female quail had significantly higher slaughtering and carcass part weights (except for the neck and other weights) and produced a greater percentage of breast meat compared with the males (Table 4). Conversely, percentages of hot carcass, cold carcass, leg, neck, and other parts of the male quail were higher than the female $(P<0.05)$. There was no consistent trend in the weights of the various carcass parts resulting from the addition of DPE. The slaughter, hot carcass, and breast weights of the $0.50 \%$ DPE group were higher than the other groups. Date palm extract and gender interaction affected the slaughter, hot carcass and leg weights $(P<0.05)$. The highest slaughter, hot carcass and leg weights were in the $1.00 \%$ DPE female, $0.75 \%$ DPE female, and $0.75 \%$ DPE female groups. The addition of $0.50 \%$ DPE and $0.75 \%$ DPE increased the hot and cold carcass yields and the breast percentage of the quail compared with the control $(P<0.05)$. 
Table 4 Effect of date palm extract supplementation on weights and percentages of components of the quail carcass

\begin{tabular}{|c|c|c|c|c|c|c|c|c|c|c|c|c|c|c|c|c|c|c|}
\hline \multirow{2}{*}{ Group } & \multirow{2}{*}{ Gender } & \multirow{2}{*}{$\begin{array}{c}\text { Slaughter } \\
\text { weight, } \\
\text { g } \\
\end{array}$} & \multicolumn{2}{|c|}{ Hot carcass } & \multicolumn{2}{|c|}{ Cold carcass } & \multicolumn{2}{|c|}{ Leg } & \multicolumn{2}{|c|}{ Breast } & \multicolumn{2}{|c|}{ Wing } & \multicolumn{2}{|c|}{ Back } & \multicolumn{2}{|c|}{ Neck } & \multicolumn{2}{|c|}{ Other } \\
\hline & & & $\begin{array}{c}\text { weight, } \\
\mathrm{g}\end{array}$ & $\%$ & $\begin{array}{l}\text { weight, } \\
\mathrm{g}\end{array}$ & $\%$ & $\begin{array}{c}\text { weight, } \\
\mathrm{g}\end{array}$ & $\%$ & $\begin{array}{c}\text { weight, } \\
\mathrm{g}\end{array}$ & $\%$ & $\begin{array}{c}\text { weight, } \\
\mathrm{g}\end{array}$ & $\%$ & $\begin{array}{l}\text { weight, } \\
\mathrm{g}\end{array}$ & $\%$ & $\begin{array}{c}\text { weight, } \\
\mathrm{g}\end{array}$ & $\%$ & $\begin{array}{l}\text { weight, } \\
\mathrm{g}\end{array}$ & $\%$ \\
\hline \multirow[t]{2}{*}{ 1.00\% DPE } & Male & $175.5^{\mathrm{cd}}$ & $129.5^{c}$ & 73.8 & 127.3 & 72.6 & $29.2^{b}$ & 22.9 & 45.4 & 35.6 & 10.5 & 8.3 & 15.9 & 12.5 & 10.0 & 7.8 & 16.3 & 12.8 \\
\hline & Female & $212.9^{\mathrm{a}}$ & $138.3^{\mathrm{ab}}$ & 65.0 & 136.1 & 64.0 & $31.1^{\mathrm{a}}$ & 22.8 & 52.2 & 38.4 & 11.0 & 8.1 & 16.6 & 12.2 & 9.1 & 6.7 & 16.1 & 11.8 \\
\hline \multirow[t]{2}{*}{$0.75 \%$ DPE } & Male & $179.2^{b c}$ & $135.0^{b}$ & 75.3 & 133.4 & 74.4 & $32.2^{\mathrm{a}}$ & 24.1 & 49.1 & 36.8 & 11.7 & 8.8 & 14.5 & 10.9 & 10.3 & 7.7 & 15.6 & 11.7 \\
\hline & Female & $211.9^{\mathrm{a}}$ & $142.9^{a}$ & 67.4 & 142.1 & 67.0 & $32.6^{\mathrm{a}}$ & 23.0 & 53.6 & 37.7 & 12.4 & 8.7 & 15.9 & 11.2 & 10.3 & 7.3 & 17.2 & 12.1 \\
\hline \multirow[t]{2}{*}{$0.50 \%$ DPE } & Male & $181.9^{b}$ & $138.2^{\mathrm{ab}}$ & 76.0 & 135.4 & 74.4 & $31.5^{\mathrm{a}}$ & 23.3 & 49.3 & 36.5 & 11.4 & 8.5 & 16.0 & 11.8 & 10.6 & 7.8 & 16.6 & 12.2 \\
\hline & Female & $211.2^{\mathrm{a}}$ & $141.8^{a}$ & 67.2 & 139.4 & 66.0 & $32.0^{\mathrm{a}}$ & 22.9 & 53.8 & 38.6 & 11.9 & 8.6 & 16.7 & 12.0 & 9.7 & 7.0 & 15.3 & 11.0 \\
\hline \multirow[t]{2}{*}{$0.25 \%$ DPE } & Male & $170.9^{d}$ & $126.5^{c}$ & 74.0 & 125.4 & 73.4 & $28.7^{\mathrm{b}}$ & 22.9 & 44.0 & 35.1 & 10.8 & 8.6 & 15.6 & 12.4 & 9.8 & 7.8 & 16.6 & 13.2 \\
\hline & Female & $210.3^{\mathrm{a}}$ & $139.5^{\mathrm{ab}}$ & 66.4 & 138.0 & 65.6 & $31.5^{\mathrm{a}}$ & 22.8 & 51.1 & 37.0 & 11.5 & 8.4 & 17.1 & 12.4 & 10.0 & 7.3 & 16.8 & 12.2 \\
\hline \multirow[t]{2}{*}{ Control } & Male & $172.1^{d}$ & $127.1^{c}$ & 73.9 & 125.4 & 72.9 & $28.9^{\mathrm{b}}$ & 23.1 & 44.8 & 35.7 & 10.5 & 8.3 & 15.1 & 12.1 & 9.6 & 7.6 & 16.5 & 13.2 \\
\hline & Female & $208.3^{\mathrm{a}}$ & $140.0^{\mathrm{ab}}$ & 67.2 & 138.3 & 66.3 & $31.5^{\mathrm{a}}$ & 22.8 & 51.2 & 37.1 & 11.7 & 8.5 & 16.6 & 12.0 & 10.0 & 7.2 & 17.2 & 12.4 \\
\hline SE & & 1.6 & 1.6 & 0.6 & 0.6 & 0.6 & 0.5 & 0.3 & 0.8 & 0.4 & 0.2 & 0.1 & 0.4 & 0.2 & 0.3 & 0.2 & 0.4 & 0.3 \\
\hline \multicolumn{2}{|l|}{ 1.00\% DPE } & $194.2^{b}$ & $133.9^{b}$ & $69.4^{c}$ & $69.4^{c}$ & $68.3^{b}$ & $30.2^{b}$ & 22.9 & $48.8^{b}$ & $37.0^{\mathrm{ab}}$ & $10.8^{c}$ & $8.2^{c}$ & $16.3^{a}$ & $12.4^{\mathrm{ab}}$ & 9.5 & 7.3 & 16.2 & $12.3^{\mathrm{ab}}$ \\
\hline \multicolumn{2}{|l|}{$0.75 \%$ DPE } & $195.6^{\mathrm{ab}}$ & $138.9^{a}$ & $71.4^{\mathrm{ab}}$ & $71.4^{\mathrm{ab}}$ & $70.7^{\mathrm{a}}$ & $32.4^{\mathrm{a}}$ & 23.6 & $51.3^{a}$ & $37.2^{\mathrm{a}}$ & $12.0^{a}$ & $8.7^{\mathrm{a}}$ & $15.2^{b}$ & $11.1^{\mathrm{c}}$ & 10.3 & 7.5 & 16.4 & $11.9^{b c}$ \\
\hline \multicolumn{2}{|l|}{$0.50 \% \mathrm{DPE}$} & $196.6^{\mathrm{a}}$ & $140.0^{a}$ & $71.6^{\mathrm{a}}$ & $71.6^{\mathrm{a}}$ & $70.2^{a}$ & $31.7^{\mathrm{a}}$ & 23.1 & $51.5^{\mathrm{a}}$ & $37.5^{\mathrm{a}}$ & $11.7^{\mathrm{a}}$ & $8.5^{\mathrm{ab}}$ & $16.4^{\mathrm{a}}$ & $11.9^{\mathrm{b}}$ & 10.1 & 7.4 & 16.0 & $11.6^{c}$ \\
\hline \multicolumn{2}{|l|}{$0.25 \%$ DPE } & $190.6^{c}$ & $133.0^{b}$ & $70.2^{\mathrm{bc}}$ & $70.2^{\mathrm{bc}}$ & $69.5^{\mathrm{a}}$ & $30.1^{b}$ & 22.9 & $47.6^{b}$ & $36.0^{c}$ & $11.2^{b}$ & $8.5^{b}$ & $16.4^{\mathrm{a}}$ & $12.4^{c}$ & 9.9 & 7.5 & 16.7 & $12.7^{\mathrm{a}}$ \\
\hline \multicolumn{2}{|l|}{ Control } & $190.2^{c}$ & $133.6^{b}$ & $70.5^{\mathrm{abc}}$ & $70.5^{\mathrm{abc}}$ & $69.6^{\mathrm{a}}$ & $30.2^{b}$ & 22.9 & $48.0^{\mathrm{b}}$ & $36.4^{\mathrm{bc}}$ & $11.1^{b c}$ & $8.4^{\mathrm{b}}$ & $15.9^{\mathrm{ab}}$ & $12.1^{\mathrm{ab}}$ & 9.8 & 7.4 & 16.9 & $12.8^{\mathrm{a}}$ \\
\hline \multicolumn{2}{|l|}{ SE } & 1.1 & 1.2 & 0.5 & 0.5 & 0.4 & 0.3 & 0.2 & 0.6 & 0.3 & 0.1 & 0.1 & 0.3 & 0.2 & 0.2 & 0.2 & 0.3 & 0.2 \\
\hline \multicolumn{2}{|l|}{ Male } & $175.9^{b}$ & $131.2^{b}$ & $74.6^{a}$ & $74.6^{a}$ & $73.5^{\mathrm{a}}$ & $30.1^{b}$ & $23.3^{a}$ & $46.5^{\mathrm{b}}$ & $35.9^{b}$ & $11.0^{b}$ & 8.5 & $15.4^{b}$ & 11.9 & 10.0 & $7.8^{a}$ & 16.3 & $12.6^{\mathrm{a}}$ \\
\hline \multicolumn{2}{|l|}{ Female } & $210.9^{\mathrm{a}}$ & $140.5^{\mathrm{a}}$ & $66.6^{\mathrm{b}}$ & $66.6^{\mathrm{b}}$ & $65.8^{b}$ & $31.7^{\mathrm{a}}$ & $22.9^{b}$ & $52.4^{\mathrm{a}}$ & $37.7^{\mathrm{a}}$ & $11.7^{\mathrm{a}}$ & 8.4 & $16.6^{\mathrm{a}}$ & 12.0 & 9.8 & $7.1^{b}$ & 16.5 & $11.9^{b}$ \\
\hline \multicolumn{2}{|l|}{ SE } & 0.7 & 0.7 & 0.3 & 0.3 & 0.3 & 0.2 & 0.1 & 0.4 & 0.2 & 0.1 & 0.1 & 0.2 & 0.1 & 0.2 & 0.1 & 0.2 & 0.1 \\
\hline \multicolumn{19}{|c|}{ Source of variation } \\
\hline \multicolumn{2}{|l|}{ DPE } & $<0.01$ & $<0.01$ & $<0.01$ & $<0.01$ & $<0.01$ & $<0.01$ & 0.11 & $<0.01$ & $<0.01$ & $<0.01$ & $<0.01$ & 0.01 & $<0.01$ & 0.15 & 0.79 & 0.26 & $<0.01$ \\
\hline Gender & & $<0.01$ & $<0.01$ & $<0.01$ & $<0.01$ & $<0.01$ & $<0.01$ & 0.04 & $<0.01$ & $<0.01$ & $<0.01$ & 0.52 & $<0.01$ & 0.82 & 0.30 & $<0.01$ & 0.44 & $<0.01$ \\
\hline DPE $\times$ gende & & 0.02 & 0.03 & 0.43 & 0.43 & 0.50 & 0.03 & 0.29 & 0.35 & 0.20 & 0.19 & 0.39 & 0.67 & 0.63 & 0.15 & 0.49 & 0.06 & 0.05 \\
\hline
\end{tabular}

DPE: date palm extract

a,b,c,d Within an effect and column, means a common superscript did not differ at probability $P=0.05$ 
Visceral organ weights and percentages of female quail (with the exception of heart and abdominal fat percentages) were higher compared with male quail $(P<0.05)$. The addition of DPE to quail rations caused an increase in the intestinal weight and percentage. However, there was a decrease in the abdominal fat weight and percentage $(P<0.05)$. When the internal organ weights and percentages were evaluated, DPE and gender interaction had no effect (Table 5).

Table 5 Effect of dietary date palm extract supplementation on organ weights and percentages relative to live body weight in male and female quail

\begin{tabular}{|c|c|c|c|c|c|c|c|c|c|c|c|}
\hline \multirow[b]{2}{*}{ Group } & \multirow[b]{2}{*}{ Gender } & \multicolumn{2}{|c|}{ Heart } & \multicolumn{2}{|c|}{ Liver } & \multicolumn{2}{|c|}{ Intestine } & \multicolumn{2}{|c|}{ Gizzard } & \multicolumn{2}{|c|}{ Abdominal fat } \\
\hline & & $\begin{array}{c}\text { weight, } \\
\mathrm{g}\end{array}$ & $\%$ & $\begin{array}{c}\text { weight, } \\
\mathrm{g}\end{array}$ & $\%$ & $\begin{array}{c}\text { weight, } \\
\mathrm{g}\end{array}$ & $\%$ & $\begin{array}{c}\text { weight, } \\
\mathrm{g}\end{array}$ & $\%$ & $\begin{array}{c}\text { weight, } \\
\mathrm{g}\end{array}$ & $\%$ \\
\hline \multirow[t]{2}{*}{$1.00 \%$ DPE } & Male & 1.56 & 0.89 & 3.08 & 1.75 & 4.97 & 2.84 & 3.43 & 1.95 & 2.12 & 1.21 \\
\hline & Female & 1.79 & 0.84 & 5.16 & 2.41 & 7.57 & 3.54 & 4.33 & 2.04 & 1.93 & 0.90 \\
\hline \multirow[t]{2}{*}{$0.75 \%$ DPE } & Male & 1.54 & 0.86 & 2.79 & 1.56 & 4.80 & 2.68 & 3.43 & 1.92 & 1.36 & 0.76 \\
\hline & Female & 1.63 & 0.77 & 5.61 & 2.66 & 6.56 & 3.10 & 4.27 & 2.02 & 1.89 & 0.89 \\
\hline \multirow[t]{2}{*}{$0.50 \%$ DPE } & Male & 1.59 & 0.88 & 3.14 & 1.73 & 4.96 & 2.72 & 3.45 & 1.90 & 1.69 & 0.93 \\
\hline & Female & 1.62 & 0.77 & 5.16 & 2.45 & 7.57 & 3.58 & 4.42 & 2.10 & 1.88 & 0.90 \\
\hline \multirow[t]{2}{*}{$0.25 \%$ DPE } & Male & 1.56 & 0.91 & 3.14 & 1.85 & 4.30 & 2.51 & 3.39 & 1.99 & 1.31 & 0.76 \\
\hline & Female & 1.71 & 0.81 & 5.12 & 2.43 & 7.59 & 3.61 & 4.43 & 2.11 & 2.13 & 1.01 \\
\hline \multirow[t]{2}{*}{ Control } & Male & 1.62 & 0.94 & 2.73 & 1.59 & 3.84 & 2.22 & 3.41 & 1.98 & 2.10 & 1.22 \\
\hline & Female & 1.71 & 0.82 & 5.17 & 2.49 & 5.60 & 2.68 & 3.97 & 1.90 & 2.42 & 1.16 \\
\hline SE & & 0.05 & 0.03 & 0.20 & 0.10 & 0.29 & 0.14 & 0.12 & 0.06 & 0.23 & 0.12 \\
\hline $1.00 \% \mathrm{DPE}$ & & 1.67 & 0.86 & 4.12 & 2.08 & $6.27^{\mathrm{a}}$ & $3.19^{\mathrm{a}}$ & 3.88 & 2.00 & $2.03^{\mathrm{ab}}$ & $1.05^{\mathrm{ab}}$ \\
\hline $0.75 \%$ DPE & & 1.58 & 0.81 & 4.20 & 2.11 & $5.68^{a}$ & $2.89^{b}$ & 3.85 & 1.97 & $1.63^{b}$ & $0.83^{b}$ \\
\hline $0.50 \%$ DPE & & 1.60 & 0.82 & 4.15 & 2.09 & $6.26^{a}$ & $3.15^{\mathrm{ab}}$ & 3.93 & 2.00 & $1.78^{\mathrm{ab}}$ & $0.91^{b}$ \\
\hline $0.25 \%$ DPE & & 1.64 & 0.86 & 4.13 & 2.14 & $5.95^{\mathrm{a}}$ & $3.06^{a b}$ & 3.91 & 2.05 & $1.72^{\mathrm{b}}$ & $0.89^{b}$ \\
\hline Control & & 1.66 & 0.88 & 3.95 & 2.04 & $4.72^{b}$ & $2.45^{\mathrm{C}}$ & 3.69 & 1.94 & $2.26^{\mathrm{a}}$ & $1.19^{a}$ \\
\hline SE & & 0.04 & 0.02 & 0.14 & 0.07 & 0.21 & 0.10 & 0.09 & 0.05 & 0.16 & 0.08 \\
\hline Male & & $1.57^{\mathrm{b}}$ & $0.89^{a}$ & $2.98^{\mathrm{b}}$ & $1.69^{b}$ & $4.57^{b}$ & $2.59^{b}$ & $3.42^{b}$ & $1.95^{b}$ & $1.71^{\mathrm{b}}$ & 0.97 \\
\hline Female & & $1.69^{\mathrm{a}}$ & $0.80^{\mathrm{b}}$ & $5.24^{\mathrm{a}}$ & $2.49^{a}$ & $6.98^{\mathrm{a}}$ & $3.30^{\mathrm{a}}$ & $4.29^{a}$ & $2.03^{a}$ & $2.05^{\mathrm{a}}$ & 0.97 \\
\hline SE & & 0.02 & 0.01 & 0.09 & 0.04 & 0.13 & 0.06 & 0.06 & 0.03 & 0.10 & 0.05 \\
\hline \multicolumn{12}{|c|}{ Source of variation } \\
\hline DPE & & 0.40 & 0.05 & 0.77 & 0.88 & $<0.01$ & $<0.01$ & 0.32 & 0.58 & 0.05 & 0.02 \\
\hline Gender & & $<0.01$ & $<0.01$ & $<0.01$ & $<0.01$ & $<0.01$ & $<0.01$ & $<0.01$ & 0.04 & 0.02 & 0.97 \\
\hline DPE $\times$ gender & & 0.38 & 0.69 & 0.17 & 0.06 & 0.07 & 0.08 & 0.35 & 0.31 & 0.25 & 0.16 \\
\hline
\end{tabular}

DPE: date palm extract

a,b,c,d Within an effect and column, means a common superscript did not differ at probability $P=0.05$

The serum TP and ALB levels were found to be higher in the female quail compared with male quail ( $P$ $<0.001$ ). The addition of DPE to quail rations decreased serum TP (with the exception of $1.00 \%$ DPE) and the ALB compared with the control group $(P<0.001)$. The DPE and gender interaction was significant regarding the TP and ALB $(P<0.001)$. The highest TP and ALB levels were indicated in the control female quail and the lowest values in the control male quail.

The serum TRIG level of male quail was lower compared with that of female quail. However, serum $\mathrm{CHOL}$ and HDL levels of female quail were lower compared with male quail $(P<0.001)$. The use of DPE as a feed additive decreased CHOL, HDL (with the exception of $0.75 \%$ DPE and $0.25 \%$ DPE), and TRIG (with the exception of $1.00 \%$ DPE and $0.75 \%$ DPE) levels compared with the control $(P<0.001)$. The DPE and gender interaction had an effect on the levels of TRIG, CHOL, and HDL $(P<0.001)$. The lowest and highest levels were determined in the $0.50 \%$ DPE male group and $1.00 \%$ DPE female group; in the $0.75 \%$ DPE female 
group and control female group; and in the $0.75 \%$ DPE female group and $0.25 \%$ DPE male group. The blood serum parameters after the addition of DPE to quail rations are presented in Table 6.

Serum ALT and AST levels were lower in female quail compared with male quail $(P<0.001)$. The addition of DPE to quail rations decreased the serum ALT activity and increased AST (with the exception of $0.75 \%$ DPE) activity when compared with the control group $(P<0.001)$. The interaction between DPE and gender affected ALT and AST $(P<0.001)$ activities. The lowest and the highest levels were detected in the $0.75 \%$ DPE female and control female groups for ALT, and in the $0.75 \%$ DPE female and $0.25 \%$ DPE female groups for AST, respectively.

Serum TAS, TOS, and OSI levels of male quail were lower compared with female quail $(P<0.001)$. The addition of $0.25 \%$ DPE and $0.50 \%$ DPE to the quail ration increased the TAS levels in the treatment groups compared with the control group, and decreased the TOS and OSI $(P<0.001)$ levels. The DPE and gender interaction had an effect on TAS, TOS, and OSI $(P<0.001)$ levels. Notably, the highest TAS level was identified in the $0.25 \%$ DPE female group and the lowest was in the $1.00 \%$ DPE female group. In addition, the lowest TOS and OSI levels were in the $0.25 \%$ DPE female group and the highest were in the $0.75 \%$ DPE female group.

The addition of DPE to the rations for quail affected LBW positively because of the phytochemicals in the date palm (Martín-Sánchez et al., 2014). In the present study, the addition of DPE increased LBW, which was consistent with results in which date fruit (Al-Dawah, 2016), whole date and date fruit (Vandepopuliere et al., 1995), and date waste (Tareen et al., 2017) were used in varying percentages in broiler rations. However, Al-Harthi (2006) and El-Deek et al. (2011) reported that the addition of date waste meal at $7 \%, 14 \%$, and $21 \%$ to broiler rations did not affect the LBW after being fed for 35 days.

Studies on broilers reported that the addition of date flesh (Taha et al.d, 2013) to the ration improved the ADG, which is consistent with the results of the present study. However, Al-Harthi (2006) and El-Deek et al. (2010) reported that the addition of date waste meal and whole inedible dates to broiler rations at various percentages did not affect ADG. However, Zangiabadi an Torki (2010) reported that the addition of whole dates to the rations from broiler chickens reduced ADG. In the current study, the addition of DPE decreased FI, which was consistent with the findings of Attia and Attia (2015) for date waste, Mohammed (2013) for date fruit and Zangiabadi and Torki (2010) for whole dates. In contrast, the addition of date waste meal (AlHarthi, 2006) and date waste (El-Deek et al., 2011) increased FI. In the present study, the addition of DPE improved the FCRs of the quail. Similarly, Abudabos et al. (2015), Attia and Attia (2015), and Mohammed (2013) reported that the addition of dates and by-products to broiler rations improved the FCR. Conversely, Al-Harthi (2006), Zangiabadi and Torki (2010), El-Deek et al. (2010), and El-Deek et al. (2011) determined that the use of date palm and its by-products as feed additives did not change FCR. This study may exhibit similarities and differences compared with other studies because of the species of poultry that is used in the studies and types of growth methods.

The significant improvements in the LBW, ADG, and FCR in female quail compared with male quail overall are consistent with the study by Bolacali and Irak (2017). Higher LBW and ADG in female quail may be associated with female hormones that stimulate fat deposition, a higher metabolic rate, and because Japanese quail are sexually dimorphic, unlike other poultry animals (Ayoola et al., 2014). Sexual dimorphism probably evolved under the pressure of natural selection, which suggests that genes that control some of the differences between males and females (Midnon-Grasteau et al., 2004). In addition, because male quail reach sexual maturity at earlier ages than females, males may expend more energy in sexual activities at earlier ages rather than in increasing their body reserves (Farooq et al., 2013).

Feed intake was possibly lower in male quail than in female quail during finisher and overall because this is the start of sexual activity, which is based on hormonal changes, which caused a decrease in the $\mathrm{FI}$ between days 30 and 40 in male quail. In addition, this is a period in which social hierarchy begins, which causes stress in animals (Seker et al., 2007). Also, greater competition for feed and water consumption in males, and aggressive behaviour as a result of social dominance suggest that gender might influence FCR (Zerehdaran et al., 2014).

In the present study, two factors played roles in the significant influence of DPE and gender interaction on growth performance during the grower and finisher phases and overall. First, DPE has antioxidant and immunostimulatory effects because of its carotenoid, phytosterol, phenolic acid, and flavonoid content, and affects live weight and growth performance with its high carbohydrate content. Isocaloric broiler rations augmented with whole inedible date to replace corn as a source of energy had no effect on digestibility of nutrients, growth performance and meat quality measurements (El-Deek et al., 2010). Second, because female quail have higher growth performances compared with males, this may be associated with the phytoestrogen content of date palm (Thompson et al., 2006). 
Table 6 Effects of date palm extract supplementation on some quail blood serum parameters at 42 days old

\begin{tabular}{|c|c|c|c|c|c|c|c|c|c|c|c|}
\hline Group & Gender & $\begin{array}{l}\text { TP, } \\
\text { g/dl }\end{array}$ & $\begin{array}{l}\text { ALB, } \\
\text { g/dl }\end{array}$ & $\begin{array}{l}\text { TRIG, } \\
\mathrm{mg} / \mathrm{dl}\end{array}$ & $\begin{array}{l}\mathrm{CHOL}, \\
\mathrm{mg} / \mathrm{dl}\end{array}$ & $\begin{array}{l}\mathrm{HDL} \text {, } \\
\mathrm{mg} / \mathrm{dl}\end{array}$ & $\begin{array}{l}\text { ALT, } \\
\text { U/L }\end{array}$ & $\begin{array}{c}\text { AST, } \\
\text { U/L }\end{array}$ & $\begin{array}{c}\text { TAS, } \\
\text { mmol trolox } \\
\text { Equiv./L }\end{array}$ & $\begin{array}{c}\text { TOS, } \\
\mu \mathrm{mol} \mathrm{H}_{2} \mathrm{O}_{2} \\
\text { equiv./L } \\
\end{array}$ & $\begin{array}{c}\text { OSI, } \\
\%\end{array}$ \\
\hline \multirow[t]{2}{*}{$1.00 \%$ DPE } & Male & $2.45^{\mathrm{e}}$ & $1.15^{\mathrm{e}}$ & $79.75^{\mathrm{fg}}$ & $194.3^{\mathrm{de}}$ & $149.30^{b}$ & $5.50 b^{c}$ & $305.75^{c}$ & $0.98^{f}$ & $9.45^{c}$ & $0.98^{b}$ \\
\hline & Female & $3.30^{b}$ & $1.45^{\mathrm{b}}$ & $844.50^{\mathrm{a}}$ & $198.3^{d}$ & $70.60^{d}$ & $4.25^{\mathrm{e}}$ & $223.00^{\text {ef }}$ & $0.93^{g}$ & $9.57^{b}$ & $1.04^{\mathrm{a}}$ \\
\hline \multirow[t]{2}{*}{$0.75 \%$ DPE } & Male & $2.60^{d}$ & $1.15^{\mathrm{e}}$ & $97.25^{\dagger}$ & $216.8^{b}$ & $164.45^{\mathrm{a}}$ & $5.75^{\mathrm{ab}}$ & $259.75^{d}$ & $1.10^{\mathrm{e}}$ & $9.17^{d}$ & $0.84^{c}$ \\
\hline & Female & $2.95^{\mathrm{C}}$ & $1.40^{\mathrm{C}}$ & $634.25^{\mathrm{b}}$ & $126.5^{g}$ & $64.28^{f}$ & $4.25^{\mathrm{e}}$ & $214.75^{f}$ & $1.00^{f}$ & $10.33^{a}$ & $1.06^{\mathrm{a}}$ \\
\hline \multirow[t]{2}{*}{$0.50 \%$ DPE } & Male & $2.45^{\mathrm{e}}$ & $1.18^{\mathrm{e}}$ & $59.75^{9}$ & $186.8^{e}$ & $151.15^{b}$ & $5.25^{\mathrm{cd}}$ & $262.75^{d}$ & $1.61^{b}$ & $8.50^{9}$ & $0.53^{\mathrm{fg}}$ \\
\hline & Female & $2.93^{\mathrm{c}}$ & $1.28^{d}$ & $487.75^{\mathrm{e}}$ & $133.5^{\mathrm{g}}$ & $66.93^{\mathrm{ef}}$ & $4.50^{\mathrm{e}}$ & $300.50^{c}$ & $1.62^{\mathrm{ab}}$ & $8.78^{f}$ & $0.54^{\dagger}$ \\
\hline \multirow[t]{2}{*}{$0.25 \%$ DPE } & Male & $2.45^{\mathrm{e}}$ & $1.15^{\mathrm{e}}$ & $87.50^{\dagger}$ & $208.5^{\mathrm{bc}}$ & $165.20^{\mathrm{a}}$ & $5.00^{d}$ & $327.25^{b}$ & $1.58^{\mathrm{C}}$ & $9.06^{\mathrm{e}}$ & $0.58^{\mathrm{e}}$ \\
\hline & Female & $2.95^{\mathrm{c}}$ & $1.38^{\mathrm{C}}$ & $570.50^{d}$ & $159.3^{f}$ & $67.85^{\mathrm{de}}$ & $5.25^{\mathrm{cd}}$ & $428.25^{\mathrm{a}}$ & $1.65^{\mathrm{a}}$ & $8.36^{h}$ & $0.51^{g}$ \\
\hline \multirow[t]{2}{*}{ Control } & Male & $2.33^{f}$ & $1.10^{f}$ & $74.00^{\mathrm{fg}}$ & $202.8^{\mathrm{cd}}$ & $148.63^{b}$ & $5.75^{\mathrm{ab}}$ & $268.00^{d}$ & $1.39^{d}$ & $8.85^{\dagger}$ & $0.66^{d}$ \\
\hline & Female & $3.43^{\mathrm{a}}$ & $1.53^{\mathrm{a}}$ & $600.75^{c}$ & $265.0^{\mathrm{a}}$ & $77.13^{c}$ & $6.00^{\mathrm{a}}$ & $231.50^{\mathrm{e}}$ & $1.62^{\mathrm{ab}}$ & $8.84^{\dagger}$ & $0.55^{f}$ \\
\hline SE & & 0.03 & 0.02 & 7.68 & 3.43 & 1.07 & 0.10 & 4.83 & 0.01 & 0.04 & 0.01 \\
\hline $1.00 \% \mathrm{DPE}$ & & $2.88^{\mathrm{a}}$ & $1.30^{\mathrm{ab}}$ & $462.13^{a}$ & $196.3^{b}$ & $109.95^{c}$ & $4.88^{\mathrm{C}}$ & $264.38^{c}$ & $0.96^{d}$ & $9.51^{b}$ & $1.01^{a}$ \\
\hline $0.75 \% \mathrm{DPE}$ & & $2.78^{b}$ & $1.28^{\mathrm{bc}}$ & $365.75^{b}$ & $171.6^{d}$ & $114.36^{b}$ & $5.00^{\mathrm{bc}}$ & $237.25^{\mathrm{e}}$ & $1.05^{c}$ & $9.75^{\mathrm{a}}$ & $0.95^{\mathrm{b}}$ \\
\hline $0.50 \% \mathrm{DPE}$ & & $2.69^{c}$ & $1.23^{\mathrm{d}}$ & $273.75^{d}$ & $160.1^{\mathrm{e}}$ & $109.04^{c}$ & $4.88^{\mathrm{c}}$ & $281.63^{b}$ & $1.61^{\mathrm{a}}$ & $8.64^{d}$ & $0.54^{d}$ \\
\hline $0.25 \% \mathrm{DPE}$ & & $2.70^{\mathrm{C}}$ & $1.26^{\mathrm{C}}$ & $329.00^{C}$ & $183.9^{c}$ & $116.53^{\mathrm{a}}$ & $5.13^{b}$ & $377.75^{\mathrm{a}}$ & $1.61^{a}$ & $8.71^{d}$ & $0.54^{d}$ \\
\hline Control & & $2.88^{\mathrm{a}}$ & $1.31^{\mathrm{a}}$ & $337.38^{c}$ & $233.9^{a}$ & $112.88^{b}$ & $5.88^{\mathrm{a}}$ & $249.75^{d}$ & $1.50^{\mathrm{b}}$ & $8.84^{c}$ & $0.60^{\mathrm{C}}$ \\
\hline SE & & 0.02 & 0.01 & 5.43 & 2.43 & 0.76 & 0.07 & 3.42 & 0.01 & 0.03 & 0.01 \\
\hline Male & & $2.46^{b}$ & $1.15^{\mathrm{b}}$ & $79.65^{b}$ & $201.8^{\mathrm{a}}$ & $155.75^{\mathrm{a}}$ & $5.45^{\mathrm{b}}$ & 284.70 & $1.33^{b}$ & $9.01^{b}$ & $0.72^{b}$ \\
\hline Female & & $3.11^{a}$ & $1.41^{\mathrm{a}}$ & $627.55^{\mathrm{a}}$ & $176.5^{\mathrm{b}}$ & $69.36^{b}$ & $4.85^{\mathrm{a}}$ & 279.60 & $1.36^{\mathrm{a}}$ & $9.18^{\mathrm{a}}$ & $0.74^{\mathrm{a}}$ \\
\hline SE & & 0.01 & 0.01 & 3.43 & 1.5 & 0.48 & 0.04 & 2.16 & 0.00 & 0.02 & 0.00 \\
\hline \multicolumn{12}{|c|}{ Source of variation } \\
\hline DPE & & $<0.01$ & $<0.01$ & $<0.01$ & $<0.01$ & $<0.01$ & $<0.01$ & $<0.01$ & $<0.01$ & $<0.01$ & $<0.01$ \\
\hline Gender & & $<0.01$ & $<0.01$ & $<0.01$ & $<0.01$ & $<0.01$ & $<0.01$ & 0.097 & $<0.01$ & $<0.01$ & $<0.01$ \\
\hline DPE $\times$ gender & & $<0.01$ & $<0.01$ & $<0.01$ & $<0.01$ & $<0.01$ & $<0.01$ & $<0.01$ & $<0.01$ & $<0.01$ & $<0.01$ \\
\hline
\end{tabular}

3 TP: total protein, ALB: albumin, TRIG: triglyceride, CHOL: total cholesterol, HDL: high-density, ALT: alanine aminotransferase, AST: aspartate aminotransferase, TAS: total antioxidant status, TOS: total oxidant status, OSI: oxidative stress index, DPE: date palm extract

${ }_{a, b, c, d}$ Within an effect and column, means with a common superscript did not differ at probability $P=0.05$ 
The current results indicated that the addition of DPE to quail rations did not change the leg percentage compared with the control, which is consistent with the results of various studies (Al-Harthi et al., 2009; El-Deek et al., 2010). The increased breast percentage with the addition of $0.50 \%$ and $0.75 \%$ DPE might be associated with the increase in slaughter weight and hot and cold carcass percentages. In addition, adding $1.00 \%$ DPE and $0.25 \%$ DPE did not affect the breast percentage, which is consistent with the results of Al-Harthi (2006) and El-Deek et al. (2010). In this study, the reason that the carcass and carcass part percentages in the DPE groups were higher compared with the control may be associated with the presence of oestrogen and certain flavonoids in the DPE (Al-Harthi et al., 2009). El-Borai and El-Borai (1988) reported that oestrogen had a stimulating effect on fat accumulation in the muscle fibres by reducing abdominal fat content.

Male quail had lower slaughtering and carcass weights than female quail. Higher carcass percentages may be associated with factors such as i) anatomical differences - male quail have larger bone weights and lighter internal organ weights than females (Bonos et al., 2010); ii) sexual dimorphism in quail - females have higher precocity than males (Aguiar et al., 2017); and iii) females have a natural genetic structure that results in higher weights in all carcass characteristics than their male counterparts (Olawumi, 2015).

The addition of DPE did not affect the relative mass of heart and liver, but increased the gizzard percentage compared with the control group. These results were consistent with the Zangiabadi and Torki (2010) study. The increased relative weight of intestine was similar to results from Al-Harthi et al. (2009). Finally, the reduced abdominal fat percentage is consistent with the results of Al-Harthi et al. (2009).

Biochemical parameters are vital for evaluating metabolic activity in animals. In this study, the addition of DPE rations decreased the TP and ALB levels in the quail, which contradicted the results of Al-Dawah (2016) and Mohammed (2013). The higher TP and ALB levels in female quail may stem from entry of the proteins in the additives into the direct blood circulation, depending on the better FCR by the females (Jassim, 2011).

In this study, the lower TRIG levels in the $0.50 \%$ DPE group compared with the control may be because of the phenolic compounds in the DPE, the use of triglycerides for energy, and its regulative effect on blood circulation (Silici et al., 2013). Date fruit is rich in phytochemicals, including carotenoids, polyphenols, tannins, and sterols (Martín-Sánchez et al., 2014).

In this study, the decreased serum cholesterol level in the DPE groups compared with the control was consistent with the findings of Abudabos et al. (2015). The decrease in CHOL levels may be associated with its removal from macrophages of the flavanol fractions in date palm (Al-Alawi et al., 2017).

Aspartate aminotransferase levels are a more liver specific indicator of liver damage than AST, ALT, and AST (Orabi \& Shawky, 2014). In the present study, reduced ALT activity following DPE treatment supports the findings of previous studies (Al-Qarawi et al., 2004; Hussein et al., 2015) that date palm and its by-products have hepatoprotective effects.

A study conducted in China examined the antioxidant activity of 28 fruits that are commonly consumed there. Date palm had the second highest antioxidant activity after hawthorn (Guo et al., 2003). A similar study found that palm cultivars had high antioxidant capacities (Mohamed Lemine et al., 2014). For example, Saafi et al. (2011) demonstrated that the DPE had a restorative effect for liver damage and protected against oxidative damage in tissues. Control of the balance between pro-oxidants and antioxidants is crucial for the maintenance of vital and biochemical functions (Ozgun et al., 2013). In recent years, it has become common to measure TOS and TAS, and calculate the OSI (Harma et al., 2003; Erel, 2004; Erel, 2005). In this study, the $0.50 \%$ DPE extract groups had the most favourable results in serum TAS, TOS, and OSI. This positive antioxidant effect may inhibit oxidation of the cell membrane with free radical activity (Borochov-Neori et al., 2015).

\section{Conclusion}

The addition of $0.50 \%$ DPE powder to the quail ration improved fattening performance and carcass yields and enhanced serum antioxidant status. Thus, it could be used as a performance enhancer for quail for the first 14 to 42 days of life.

\section{Acknowledgments}

The authors give special thanks to Ozgur Yasar Celik for his assistance in the breeding process of quail.

\section{Authors' Contributions}

$\mathrm{MB}$ was in charge of organizing the the research. $\mathrm{MB}, \mathrm{KI}, \mathrm{TT}$, and $\mathrm{MK}$ took responsibility for the logical interpretation and presentation of the results. MB, KI, and TT wrote the manuscript.

\section{Conflict of Interest Declaration}

The authors declare there was no conflict of interest. 


\section{References}

Abudabos, A.M., Abdelrahman, M.M., Suliman, G.M. \& Al-Sagan, A.A., 2015. Effect of whole inedible date and amino acid supplementation on growth performance of Ross 308 broiler chicks. Anim. Rev. 2(1), 9-18. DOI: 10.18488/JOURNAL.AR/2015.2.1/101.1.9.18

Aguiar, G.C., Freitas, E.R., Watanabe, P.H., Figueiredo, C.W.S., Silva, L.P., Nascimento, G.A.J., Lima, R.C., Nepomuceno, R.C. \& Sá, N.L., 2017. Lighting programs for male and female meat quails (Coturnix coturnix) raised in equatorial region. Poult. Sci. 96(9), 3122-3127. DOI: 10.3382/ps/pex103

Ahmad, S., Mehmood, S., Javed, K., Mahmud, A., Usman, M., Rehman, A., Ishaq, H.M., Hussain, J. \& Ghayas, A., 2018. Different selection strategies for the improvement of the growth performance and carcass traits of Japanese quail. Brazilian J. Poult. Sci. 20(3), 497-506. DOI: 10.1590/1806-9061-2018-0733

Al-Alawi, R.A., Al-Mashiqri, J.H., Al-Nadabi, J.S.M., Al-Shihi, B.I. \& Baqi, Y., 2017. Date palm tree (Phoenix dactylifera L.): Natural products and therapeutic options. Frontiers Plant Sci. 8, 845. DOI: 10.3389/fpls.2017.00845

Al-Dawah, N.K., 2016. Evaluation of the effect of dates Al-Zahdi addition in broiler chicken diet on some chemical parameters and body weight. Kufa Journal for Veterinary Medical Science 7(1), 35-40.

Al-Harthi, M.A., El-Deek, A.A., Yakout, H.M., \& Al-Refaee, M., 2009. The nutritive value of date waste meal as a feedstuff for Lohmann Brown pullets and layers. J. Poult. Sci. 46(4), 303-312. DOI: 10.2141/JPSA.46.303

Al-Harthi, M.A., 2006. The influence of date waste meal supplemented with either enzymes, probiotics or their combination on broiler performance. Egypt Poult. Sci. 26(3), 1031-1055.

Al-Salhie, K.C.K., Shawket, T.F., \& Lehmood, B.A.M., 2017. Effect of supplementation date palm pollen on some physiological and reproductive traits of Japanese quail birds (Coturnix coturnix japonica). Iraqi J. Agric. Sci. 48(6), 1389-1398.

Al-Qarawi, A.A., Mousa, H.M., Ali, B.H., Abdel-Rahman, H. \& El-Mougy, S.A., 2004. Protective effect of extracts from dates (Phoenix dactylifera L.) on carbon tetrachloride-induced hepatotoxicity in rats. International J. Appl. Res. Vetr. Med. 2(3), 176-180.

Attia, Y.A. \& Al-Harthi, M.A., 2015. Effect of supplementation of date waste to broiler diets on performance, nutrient digestibility, carcass characteristics and physiological parameters. European Poult. Sci., 79, 1-10.

Ayoola, A.A., Adeyemi, O.A., Egbeyale, L.T., Sogunle, O.M., \& Ekunseitan, D.A., 2014. Effects of sex and stocking density on growth performance and some physiological traits of Japanese quails (Coturnix coturnix Japonica). Malaysian J. Anim. Sci. 17(2), 43-53.

Belal, I.E., Al-Jasser, M.S., Mustafa, I.A. \& AI-Dosari, M.N., 1999. Evaluation of date-feed ingredients mixes. Anim. Feed Sci. and Tech. 81(3-4), 291-298. DOI: 10.1016/S0377-8401(99)00091-7

Bolacali, M. \& Irak, K. 2017. Effect of dietary yeast autolysate on performance, slaughter, and carcass characteristics, as well as blood parameters, in quail of both genders. S. Afr. J. Anim. Sci. 47(4), 460-470. DOI: 10.4314/SAJAS.V4714.5

Bonos, E.M., Christaki, E.V. \& Paneri, P.C. 2010. Performance and carcass characteristics of Japanese quail as affected by sex or mannan oligosaccharides and calcium propionate. S. Afr. J. Anim. Sci. 40(3), 173-184. DOI: 10.4314/SAJAS.V4013.2

Borochov-Neori, H., Judeinstein, S., Greenberg, A., Volkova, N., Rosenblat, M. \& Aviram, M., 2015. Antioxidant and antiatherogenic properties of phenolic acid and flavonol fractions of fruits of 'Amari' and 'Hallawi' date (Phoenix dactylifera L.) varieties. J. Agricultural \& Food Chemistry 63(12), 3189-3195. DOI: 10.1021/jf506094r

Castanon, J.I.R., 2007. History of the use of antibiotic as growth promoters in European poultry feeds. Poult. Sci. 86(11), 2466-2471. DOI: 10.3382/PS.2007-00249

El Abed, H., Chakroun, M., Abdelkafi-Koubaa, Z., Drira, N., Marrakchi, N., Mejdoub, H. \& Khemakhem, B., 2018. Antioxidant, anti-Inflammatory, and antitumoral effects of aqueous ethanolic extract from Phoenix dactylifera $L$. parthenocarpic dates. BioMed Res. International vol. 2018, article ID 1542602, 1-7. DOI: 10.1155/2018/1542602

El-Borai, M. \& El-Borai, H. 1988. Anatomy and physiology of human. Egyptian Anglo Bookshop, Cairo. Pp. 296.

El-Deek, A.A., Al-Harthi, M.A. \& El Banoby, M.M., 2011. The use of date waste in broiler nutrition. Proceedings of Egg Meat Symposia Leipzig, Germany, 4-8 September 2011. http://www.wpsa.com/index.php/publications/wpsaproceedings/3597-the-use-of-fate-waste-in-broiler-nutrition

El-Deek, A.A., Attia, Y.A. \& Al-Harthi, M.A., 2010. Whole inedible date in the grower-finisher broiler diets and the impact on productive performance, nutrient digestibility and meat quality. Animal 4(10), 1647-1652. DOI: $10.1017 / \mathrm{S} 1751731110000820$

Erel, O., 2004. A novel automated direct measurement method for total antioxidant capacity using a new generation, more stable ABTS radical cation. Clin. Biochem. 37(4), 277-285. DOI: 10.1016/J.CLINBIOCHEM.2003.11.015

Erel, O., 2005. A new automated colorimetric method for measuring total oxidant status. Clin. Biochem. 38(12), 11031111. DOI: $10.1016 /$ J.CLINBIOCHEM.2005.08.008

FAO, 2021. FAOSTAT statistics database. http://www.fao.org/faostat/en/\#data/QC

Farooq, U., Malecki, I.A., \& Greeff, J., 2013. The growth and sexual maturity of the Australian meat-type Japanese quail. In: 24th Annual Australian Poult. Sci. Symp. 2013, Sydney, Australia. P. 264.

Genchev, A. \& Mihaylov, R., 2008. Slaughter analysis protocol in experiments using Japanese quails (Coturnix coturnix Japonica). Trakia J. Sci. 6(4), 66-71.

Guo, C., Yang, J., Wei, J., Li, Y., Xu, J. \& Jiang, Y., 2003. Antioxidant activities of peel, pulp and seed fractions of common fruits as determined by FRAP assay. Nutr. Res. 23(12), 1719-1726. DOI: 10.1016/J.NUTRES.2003.08.005 
Harma, M., Harma, M. \& Erel, O., 2003. Increased oxidative stress in patients with hydatidiform mole. Swiss Medical Weekly 133, 563-566.DOI: 10.4414/SMW.2003.10397

Hussein, A.M., El-Mousalamy, A.M., Hussein, S.A. \& Mahmoud, S.A., 2015. Effects of palm dates (Phoenix dactylifera L.) extracts on hepatic dysfunctions in Type 2 diabetic rat model. World J. Pharmaceutical Sci. 4(7), 62-79.

Jassim, J.M., Riyad, K.M., Majid, H.A. \& Yanzhang, G., 2011. Evaluation of physical and chemical characteristics of male and female duck carcasses at different ages. Pakistan J. Nutr. 10(2), 182-189. DOI: 10.3923/PJN.2011.182.189

Martín-Sánchez, A.M., Cherif, S., Ben-Abda, J., Barber-Vallés, X., PérezÁlvarez, J.Á. \& Sayas-Barberá, E., 2014. Phytochemicals in date co-products and their antioxidant activity. Food Chem. 158(1), 513-520. DOI: 10.1016/j.foodchem.2014.02.172

Midnon-Grasteau, S., David, J., Gibert, P., Legout, H., Petavy, G., Moreteau, B. \& Beaumont, C., 2004. REML estimates of genetic parameters of sexual dimorphism for wing and thorax length in Drosophila melanogaster. J. Genetics 83(2), 163-170. DOI: 10.1007/BF02715899

Mohamed Lemine, F.M., Mohamed Ahmed, M.V., Ben Mohamed Maoulainine, L., Bouna Zel A., Samb, A. \& O Boukhary, A.O. 2014. Antioxidant activity of various Mauritanian date palm (Phoenix dactylifera L.) fruits at two edible ripening stages. Food Sci. Nutr. 2(6), 700-705. DOI: 10.1002/fsn3.167

Mohammed, M.F., 2013. The influence of adding date to broiler diet on performance and blood characters. International J. Adv. Biotech. Res. 3(4), 540-544.

Nagib, H., Al-Yousef, Y.M. \& Hmeidan, M., 1994. Partial replacement of corn with dates in layer diet. J. Appl. Anim. Res. 6(1), 91-96. DOI: 10.1080/09712119.1994.9706028

NRC, 1994. Nutrient requirements of domestic animals. Nutrient requirements of poultry. 9th ed. Washington, National Academic Press, USA.

Olawumi, S.O., 2015. Carcass characteristics of Coturnix quail as affected by sex and housing system. International J. Agric., Forestry Fisheries 3(3), 76-79.

Orabi, S.H. \& Shawky, S.M., 2014. Effect of date palm (Phoenix dactylifera) seeds extracts on hematological, biochemical parameters and some fertility indices in male rats. International J. Sci., Basic and Appl. Res. 17, 137147.

Ozgun, E., Ozgun, G.S., Eskiocak, S., Yalcin, O. \& Gokmen, S.S., 2013. Effect of L-carnitine on serum paraoxonase, arylesterase and lactonase activities and oxidative status in experimental colitis. Turkish J. Biochem. 38(2), 145153. DOI: 10.5505/TJB.2013.29292

Romano, B., Pagano, E., Montanaro, V., Fortunato, A.L., Milic, N. \& Borrelli, F., 2013. Novel insights into the pharmacology of flavonoids. Phytotherapy Res. 27(11), 1588-1596. DOI: 10.1002/ptr.5023

Saafi, E.B., Louedi, M., Elfeki, A., Zakhama, A., Najjar, M.F., Hammami, M. \& Achour, L., 2011. Protective effect of date palm fruit extract (Phoenix dactylifera L.) on dimethoate induced-oxidative stress in rat liver. Experimental \& Toxicologic Pathology 63(5), 433-441. DOI: 10.1016/j.etp.2010.03.002

Salem, G.A., Shaban, A., Diab, H.A., Elsaghayer, W.A., Mjedib, M.D., Hnesh, A.M. \& Sahu, R.P., 2018. Phoenix dactylifera protects against oxidative stress and hepatic injury induced by paracetamol intoxication in rats. Biomedicine \& Pharmacotherapy 104, 366-374. DOI: 10.1016/j.biopha.2018.05.049

Sami, A., Suliman, G., Abudabos, A. \& Abdelrahman, M., 2016. Effect of feeding different levels of date pits with growth promoters on carcass characteristics and meat quality merits of Naimi lambs. Pakistan J. Agric. Sci. 53(3), 713717. DOI: 10.21162/PAKJAS/16.4308

Seker, I., Bayraktar, M., Kul, S. \& Ozmen, O., 2007. Effect of slaughter age on fattening performance and carcass characteristics of Japanese quails (Coturnix coturnix Japonica). J. Appl. Anim. Res. 31(2), 193-195. DOI: 10.1080/09712119.2007.9706662

Silici, S., Özkan, M., Kara, K. \& Güçlü, B.K., 2013. Influence of propolis, caffeic acid and ferulic acid addition to Japanese quail (Coturnix Coturnix Japonica) diets on performance, carcass quality and some biochemical parameters. Erciyes Universitesi Veteriner Fakultesi Dergisi 10(3), 157-164.

Taha, H.J.A., Mayada, F.M. \& Firase, M.H.A., 2013. Effect of addition different levels of dates flesh (Phoenix dactyliphera $\mathrm{L})$ to ration contain probiotic on broiler chickens performance reared under heat stress. International J. Adv. Biotech. Res. 3(2), 306-311.

Tareen, M. H., Wagan, R., Siyal, F. A., Babazadeh, D., Bhutto, Z. A., Arain, M. A. \& Saeed, M. (2017). Effect of various levels of date palm kernel on growth performance of broilers. Vetr. World 10(2), 227-232. DOI: 10.14202/vetworld.2017.227-232

Thompson, L.U., Boucher, B.A., Liu, Z., Cotterchio, M. \& Kreiger, N., 2006. Phytoestrogen content of foods consumed in Canada, including isoflavones, lignans, and coumestan. Nutr. Cancer 54(2), 184-201. DOI: $10.1207 / \mathrm{s} 15327914$ nc5402_5

Tufan, T., \& Arslan, C. (2020). Dietary supplementation with chitosan oligosaccharide affects serum lipids and nutrient digestibility in broilers. S. Afr. J. Anim. Sci. 50(5), 663-671. DOI: 10.4314/sajas.v50i5.3

Vandepopuliere, J.M., Al-Yousef, Y. \& Lyons, J.J., 1995. Dates and date pits as ingredients in broiler starting and coturnix quail breeder diets. Poult. Sci. 74(7), 1134-1142. DOI: 10.3382/PS.0741134

Zangiabadi, H. \& Torki, M., 2010. The effect of a beta-mannanase-based enzyme on growth performance and humoral immune response of broiler chickens fed diets containing graded levels of whole dates. Trop. Anim. Health Prod. 42(6), 1209-1217. DOI: 10.1007/s11250-010-9550-1

Zerehdaran, S., Lotfi, E. \& Rasouli, Z., 2014. Genetic evaluation of meat quality traits and their correlation with growth and carcase composition in Japanese quail. Brit. Poult. Sci. 53(6), 756-762. DOI: $10.1080 / 00071668.2012 .746445$ 